\title{
Brazilian Plecoptera 3. Macrogynoplax veneranda sp. n. (Perlidae : Acroneuriinae)
}

\author{
C.G. Froehlich 1
}

A second species of the genus Macrogynoplax, hitherto known only from northern South America, is described from the State of Sảo Paulo, in southeastern Brazil.

Plecoptères brésiliens 3. Macrogynoplax veneranda sp. n. (Perlidae: Acroneuriinae).

L'auteur décrit une deuxième espèce du genre Macrogynoplax. Cette espèce a été récoltée dans l'Etat de Sāo Paulo, dans le Sud-Est du Brésil, alors que ce genre n'était connu que de la partie septentrionale de l'Amérique du Sud.

\section{Macrogynoplax veneranda sp.n.}

General colour light green in life due to a haemolymph pigment : wings very pale ; preserved specimens pate yellowish to ochraceous. Distance between ocelli a little larger than distance from each ocellus to inner margin of the eye. Head and pronotum, Fig. 1. Fore wings $18.5 \mathrm{~mm}$ long in male holotype, 16.7 and $16.5 \mathrm{~mm}$ long in male paratypes ; 17.7 to $19.7 \mathrm{~mm}$ long $(\overline{\mathrm{X}}=18.6 \mathrm{~mm}, \mathrm{~s}=0.80, \mathrm{~N}=$ 5 ) in fermale paratypes. $R_{s}$ with $4-5$ branches.

Male.

Subgenital plate large, roughly elliptical, narrowed at base ; ventral knob rounded, bordered by long bristles basally and laterally (Fig. 2). Tergite $X$ (Fig. 3) with a pair of posteromedial fields of modified hairs or bristles, some of them short and thick (Fig. 4): median strip bare. Paraprocts with a suba. pical tooth and small hairs at the top (Fig. 5). Penial armature (Figs. 6-8) without a basal ring, lateral bars broader dorsobasally and apically, supporting apically a pair of lateral folds : penis tip membranous with sparse small hairs, small hairs also present ventrally between the lateral bars. Everted penis, Fig. 9 .

Female.

Subgenital plate large, covering about half of sternite IX, sternite VIII with a basal reniform elevation and a central depression (Figs. 10-11). Sternite IX with a pair of heavily sclerotized bars, without any special tract of larger hairs (Fig. 12). Tergite $X$

1. Departamento de Biologia FFCLRP, Universidade de Sào Paulo, 14100 Ribeirào Preto, SP. Brasil. unmodified, a small elongate median area bare (Fig. 13).

Nymph.

General habitus similar to that of a Kempnyia nymph, but with only two well-spaced ocelli, and fore legs with dilated femora and curved, raptorial tibiae. A pair of anal gills present, in addition to the normal thoracic gills. General colour ochraceous to ferrugineous.

Material.

Male holotype : Estação Biológica de Boracéia, Salesópolis Municipality, $850 \mathrm{~m}$, State of São Paulo, 2 Nov. 1968, at light, H.M. Canter col. Paratypes : female, ibid., $12 \mathrm{Apr}$. 1944, L. Travassos $F^{\circ}$ and E.X. Rabello col. ; male, female, ibid., 13-18 Apr. 1961. H. Reichardı col. : male, Estaçāo Biológica de Paranapiacaba, SP, 19 July 1963, C.G. Froehlich col. ; female, ibid., 23 Apr. 1964, emerged in the laboratory, C.G. Froehlich col. ; female, Estação Biológica de Boracéia, SP, 14 Feb. 1973, S. A. Vanin col. : fernale, ibid., 9 Oct. 1977, flying in the afternoon, C.G. Froehlich col.

Etymology.

Veneranda, after Ribeirào Venerando, a stream inside the Biological Station of Boracéia, source of the larger part of the material, and where nymphs are common under stones or between fallen leaves retained by obstacles.

\section{Discussion}

The genus Macrogynoplax was known from its single described species, $M$. guayanensis End., from northern South America (Guyana, and State of Pará, Brazil). Zwick (1973) redescribed both the male and the female from Enderlein's material. The present species agrees with its northern congener by the presence of only two well-spaced ocelli, the rounded ventral knob of the male subgenital plate, the general characteristics of the male tenth tergite, and the large female subgenital plate; this plate however, 

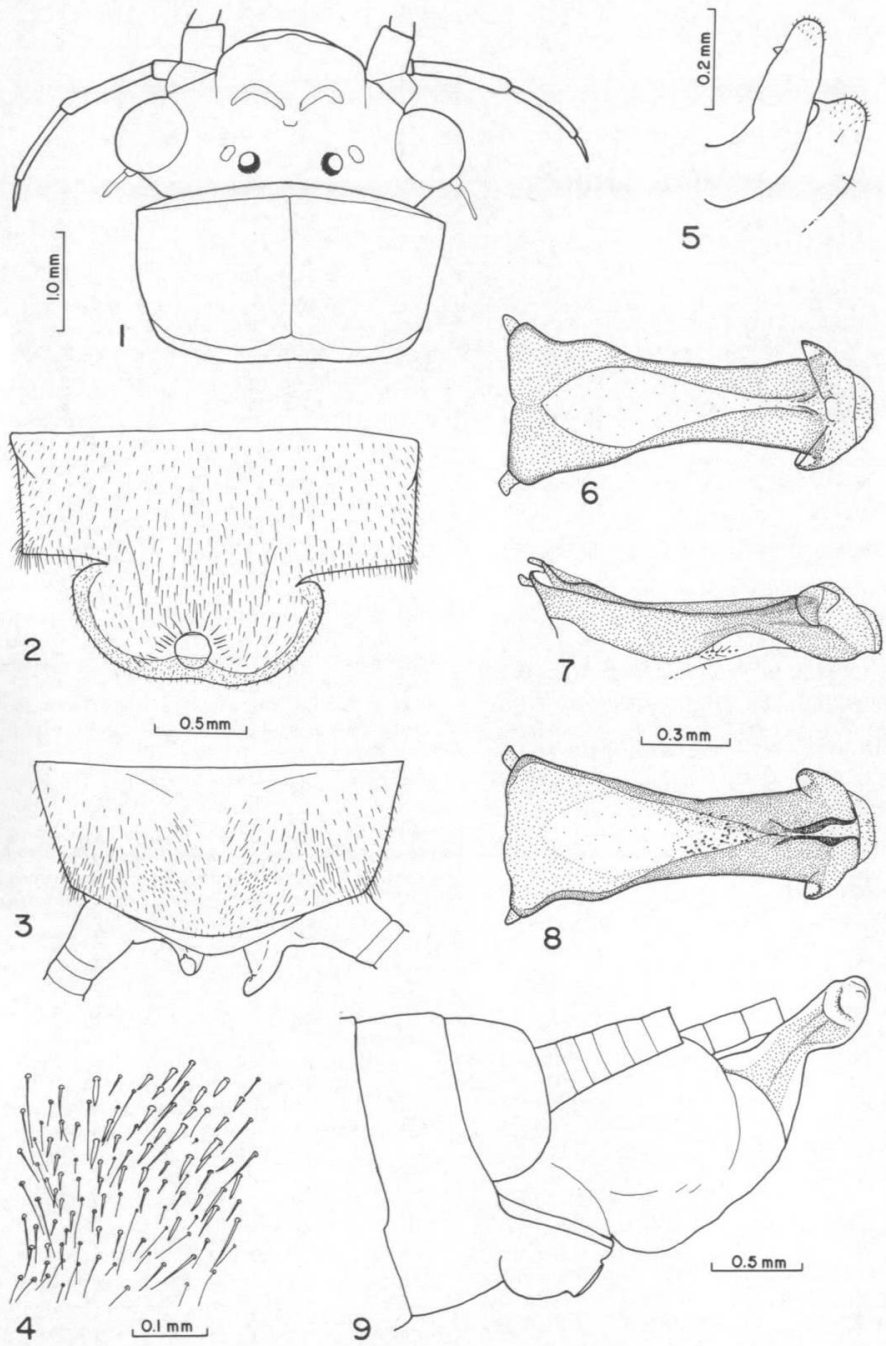

Fig. 19. Macrogynoplax veneranda sp. $\mathrm{n} .1$ : Female paratype (9.X.77), head and prothorax, dorsal view. 2-8 : Male holotype ; 2 , sternite IX and subgenital plate; 3 , tergite $X ; 4$, enlarged portion of tergite $X$, showing the posteromesial field of modified hairs and bristles: 5 , left and right paraprocts, from the left side; 6.8 , penis in dorsal, lateral and ventral views, respectively. 9 : Male paratype (19.VII.63), everted penis. 
